\title{
Transforming Forest Conflicts: Learning from North-South Conflicts over Community Forests in Terai Region of Nepal
}

\author{
Naya S Paudel ${ }^{1}$, Prabin Bhusal ${ }^{2}$, Paul Thompson ${ }^{3}$, Parvin Sultana ${ }^{3}$ \\ Anukram Adbikary ${ }^{1}$ and Kamal Bhandari ${ }^{1}$
}

${ }^{1}$ ForestAction Nepal, Kathmandu, Nepal ${ }^{2}$ Institute of Forestry, Pokhara Campus, Tribhuvan University, and ${ }^{3}$ Flood Hazard Research Centre, Middlesex University, London, UK

Corresponding author: nspaudel@gmail.com

\begin{abstract}
Continued forest conflicts in Nepal's Terai have not only undermined sustainable forest management in the region but have also contributed to emerging social unrest that can undermine transition towards new federal Nepal. Using an action research approach involving intensive participatory research methods, this paper shares experiences of current initiatives and their challenges in transforming forest-conflicts between the northern communities and southern communities in the Terai region of Nepal. The action research process helped bring the conflicting communities together, develop a shared understanding through participatory resource assessment and analysis of socio-institutional processes among the conflicting communities, and help devise a widely acceptable benefit sharing arrangement. Consequently, there has been a substantial reduction in conflict through an inclusive and extended governance arrangement. Consideration of traditional use of forests by distant as well as adjacent communities will be helpful to reduce potential heightening of conflicts in the face of policies that emphasises more on protection and restoration of forest as a response to historical trend of deforestation and emerging threats of climate change. Finally, we suggest that enabling policies including further devolution of forest management rights to local communities and adoption of adaptive approach to resource and institutional management can help mitigate northern communities-southern communities' ${ }^{1}$ conflict in Terai.
\end{abstract}

Key words: Action research, cooperation, forest conflict, Terai, transformation

\section{INTRODUCTION}

Conflicts over access, management and use of forest in the Terai(lowland) region of Nepal have significant ecological, economic and social ramifications. Terai forests are often regarded as the battlefields between competing land use (Shrestha and Conway 1996) and conflicts exist at multiple levels (Satyal and Humphreys 2012). Accordingly, forest management in Terai takes central stage in policy debate (Baral et al. 2006), academic exploration (Ojha 2007; Sinha 2011) and everyday struggle (Ghimire 1992; Conway et al. 2000).

Terai has been an experimental field of multiple, sometimes competing and even conflicting, policies and institutions. Starting from the clearance of large tracts of forests and expansion of agricultural lands in the early $20^{\text {th }}$ century to inviting people from across the border and the hills for populating the area whilst complementing with

\footnotetext{
${ }^{1}$ We have used the term northern communities-southern communities conflict to refer to the long standing conflicts over access, management and use of forests along the Chure and its foothills. 'northern communities' normally refers to the hill migrants settled along the East-West highway and its northern communities and 'southern communities' refers to the Madhesis population, traditional user of the same forests who largely settled in the southern communities part of terai close to Nepal-India border. In forest policy terminology in Terai; the people from the southern communities are also called as distant users.
} 
associated infrastructure coupled with strict protection since the 1970s are some of the examples. However, in the post 2000 context, the government took a more centrally planned and supported initiatives namely the collaborative forest management $(\mathrm{CFM})^{1}$ and public land forestry (PLF) ${ }^{2}$ to increase southern communities access to forests. At the same time, community forestry (CF) which was flourishing in the hills was seen to be potentially incompatible to address the southern communities' need and therefore was promoted with caution. There was hardly any genuine attempt to revisit the hill model of CF and explore its potential roles in increasing southern communities' access to forest.

About 76.45 per cent $(314,660$ hectares - ha) of total forests in the Terai are outside Protected Areas (PAs) (DFRS 2014) and more than 60 per cent of it is under government managed forest which can fall either under the CF or CFM regime. Given the huge scope of CF's potential contribution to increasing southern communities' access to forest products, it is worth to examine such a possibility. What is the prospect of $\mathrm{CF}$ accommodating southern communities? What can facilitate north-south dialogue in CF in Terai? What kinds of research and evidence help informed dialogue and facilitate negotiation between them? How can national policies and associated supports encourage such initiatives? This paper seeks to answer these questions so that further research and piloting can be encouraged and supported. We took a case from Chisapani community forest users group (CFUG) in Nawalparasi to illustrate the experimentation, its prospects and challenges, and lessons for any further piloting of such approach.

The paper is structured into five sections. The following section revisits policy interventions in Terai forest managementparticularly those that were introduced in response to the northern communitiessouthern communities' conflict. The third section highlights the Chisapani case, with details on the nature of conflict, CFUG's initiative in fostering northern communities-southern communities' dialogue, recent changes in institutional features and distributional arrangements, and observed outcomes. It is followed by the section highlighting key patterns of this experimentation and its lessons. Finally, we conclude the paper with few suggested areas that require policy discerning or further research.

\section{GOVERNMENT INTERVENTIONS AND CONTINUED CONFLICT}

As the expansion of $\mathrm{CF}$ reached its climax in the late 1990s, the likelihood of undermining southern communities' access to Terai forest emerged as the key policy debate. The policy orientation, legal provisions, support agencies' understanding and institutional practice of the CFUGs largely prioritised nearby inhabitants (northern communities), that resulted in a gradual exclusion of southern communities from the process. The initial concerns gradually became evident so that

${ }^{2}$ CFM is a collaborative management modality between forest department, local government and local communities which include both northern communities and southern communities.

${ }^{3}$ The term PLF is used here to refer to the government programme to promote forestry in public land which are outside of legally recognised forest lands and are often owned by local public institutions such as local governments, schools, temples etc. 
the 'exclusion of southern communities' became a critical limitation of the $\mathrm{CF}$ programme. Realising this limitation, the government experimented with a number of policy interventions such as CFM and PLF. However, these management modalities have had limited impacts so far in addressing the forest product needs of the southern communities.

Till date, only 28 CFMs with a total area of 70,138.52 ha have been handed over across Terai involving 720,662 households (HHs) (personal communication with $\mathrm{Mr}$. Shantaram Baral, Assistant Forest Officer, Department of Forest, April 2017). A large part of Terai forest is either under PA system $(96,921 \mathrm{ha})$ or under Chure environmental protection area $(1,373,743$ ha) or has already been handed over as CF (314,997 ha) (DFRS 2014) leaving limited potential forest area for expansion of the CFM. Given that 50.27 per cent population of Nepal reside in Terai (CBS 2011) of which more than half of the population lives in the Terai, supply of forest products from these few CFMs can be regarded as close to insignificant. Apart from timber, there is also a huge gap between the demand and supply of fuelwood in the south.

Large and complex institutional arrangements and exhaustive regulatory provisions pertaining to CFM allow minimum involvement of local communities in decisions regarding forest management and benefit sharing. One single group covers over 25,000 (national average) $\mathrm{HH}$ s from hundreds of settlements so that the power disperses nowhere. As the Implementing Unit of CFM is the key authority for almost all types of decisions, the group itself can exercise little influence over the decisions being made. The Implementing Unit is led by District Forest Office (DFO) and therefore, the decisions and overall functioning of CFM is heavily skewed towards government forest agency. Moreover, current forest management and harvest of CFM is constrained by administrative, technical and institutional capacity of the CFM group and associated institutions. While the recently introduced scientific forest management may to some extent increase supply of forest products to the members, this is way below the overall demand in the region.

Public Land Management (PLM) is another important approach that the government has adopted in last decade or so in order to enhance forest products for the southern communities. It has been one of the priority activities of the forestry projects and non-government organisation (NGO) actions in Terai. These are small patches of barren lands, ponds, roadsides, river/canal banks (average size: 2-4 ha) usually owned by local governments, schools, religious bodies and other public institutions at the local level (LFP 2003).

Afforestation programmes through the formation of Public Land Management Groups (PLMGs) comprising of $75-100$ $\mathrm{HHs}$ in each community and providing them with needed support including livelihood generating schemes are the key features of PLM. However, PLMGs are primarily led by forestry projects and is yet to be mainstreamed into the legal framework (forest policy and legal environment). For example, there are 235 PLMGs involving $37,143 \mathrm{HHs}$ in three districts of Western Terai (Nawalparasi, Rupandehi and Kapilvastu) supported by 
the Multi Stakeholder Forestry Program (MSFP 2015). Though project reports have hailed the scheme as a successful approach, given their small sizes and huge number of $\mathrm{HHs}$ involved, their contribution in terms of addressing the increasing need for forest product in the southern communities is again close to insignificant.

Similarly, the lack of enabling legal arrangements for sustainable management and utilisation of forest products, particularly the tenure security of PLMGs in harvesting and selling is a critical issue. Absence of clear policy provision on handover of public land to communities has created a sense of lack of ownership. For example, the ownership of land lies with the Local Governments while the DFO provides approval for the utilisation of the forest products. However, there is no clarity on whether the DFO is the appropriate institution for other land uses like construction of fish ponds and agroforestry among others. Moreover, the scheme is still perceived as a developmental project launched by some NGO and thus has not been fully owned by the PLMGs.
The above discussion shows the limitations of two major strategies in addressing forest product needs of the southern communities. In this context, it is logical to explore other available options. Since over 314,997 ha of forests are being managed under the CF regime in Terai (DFRS 2014), exploring its potential role in contributing to complement with other approaches could be a good option. The paper brings field experiences of recent initiatives by Chisapani CFUG in Nawalparasi district.

\section{CHISAPANI CFUG - AN OVERVIEW}

With the forest area of 495 ha managed collectively by $3350 \mathrm{HHs}$, Chisapani CFUG was established in 1997 and formally registered in 2009. Covering five wards, the CFUG lies in Bardaghat municipality in low land Terai of Nawalparasi district. The vegetation cover comprises of roughly 70 per cent of natural Sal (Shorea robusta) forest with significant number of trees, poles and saplings in addition to moist deciduous vegetation type of the Terai region. The forest is concentrated in the northern part from the East-West highway up to the foothill of the Churia. The settlement ranges from the southern part of the forest up to $18 \mathrm{~km}$ far, all the way to the Indian border (Figure 1). 


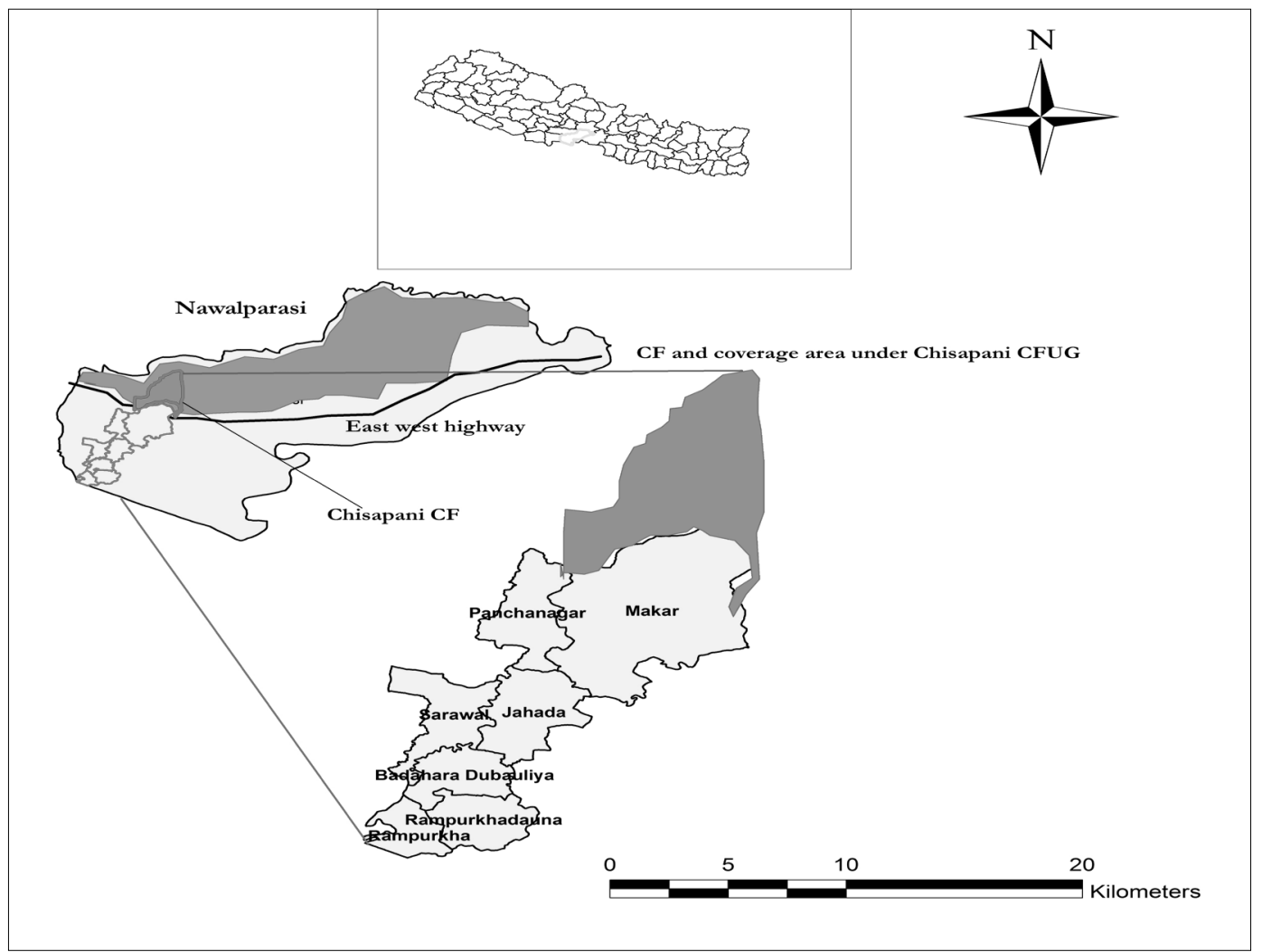

Figure 1: Map of Chisapani CF and Settlements of Member HHs

The CFUG has been providing the $\mathrm{HH}$ living around the forest with timber, fuelwood and other forest products. However, the formation of the CFUG led to the exclusion of 60 per cent of traditional users (about 2,000 HHs) as far as $18 \mathrm{~km}$ towards the south. These distant users need timber and fuelwood as they have no alternatives for construction and cooking. Consequently, they have been forced to adopt illegal/unsustainable measures whereby they collect resources often during the night in order to meet their daily needs. In doing so, they have been caught and fined several times. Gradually, conflict emerged between the northern communities and southern communities. The growing conflict sometimes turned into violent fights with large number of people from the south coming in mass and transporting unsustainably harvested cartloads of timber and fuelwood that posed challenges to the very sustainability of the forest.

Upon realising the multiple threats from this growing conflict, the community forest leaders in consultation with the DFO and other stakeholders decided to take a more inclusive approach to forest management. They invited leaders of the southern communities and began to explore ways to include them in forest management and benefit sharing. During this process, ForestAction embarked on a participatory action research (PAR) (Figure 2) aimed at understanding and 
mitigating conflicts through adaptive learning. First, the research team initiated dialogue with Chisapani CFUG leaders and jointly assessed the nature of conflict and its potential consequences. Various activities were carried out including resource assessment, stakeholder meetings, reflective workshops with CFUGs and southern communities, and exploring efficient and equitable distribution arrangements, with the aim to help mitigate the conflict. After the initial review of the situation, the executive members appeared enthusiastic and expressed their commitment to support the adaptive learning approach. An Adaptive Learning Group (ALG) comprising of community forest leaders, southern communities and research team (altogether 20 people) was formed. Subsequently step-by-step plan of a collective inquiry, reflective workshops, mutual visits between northern communities and southern communities, joint planning and implementation of management plan and monitoring of the progress was carried out.

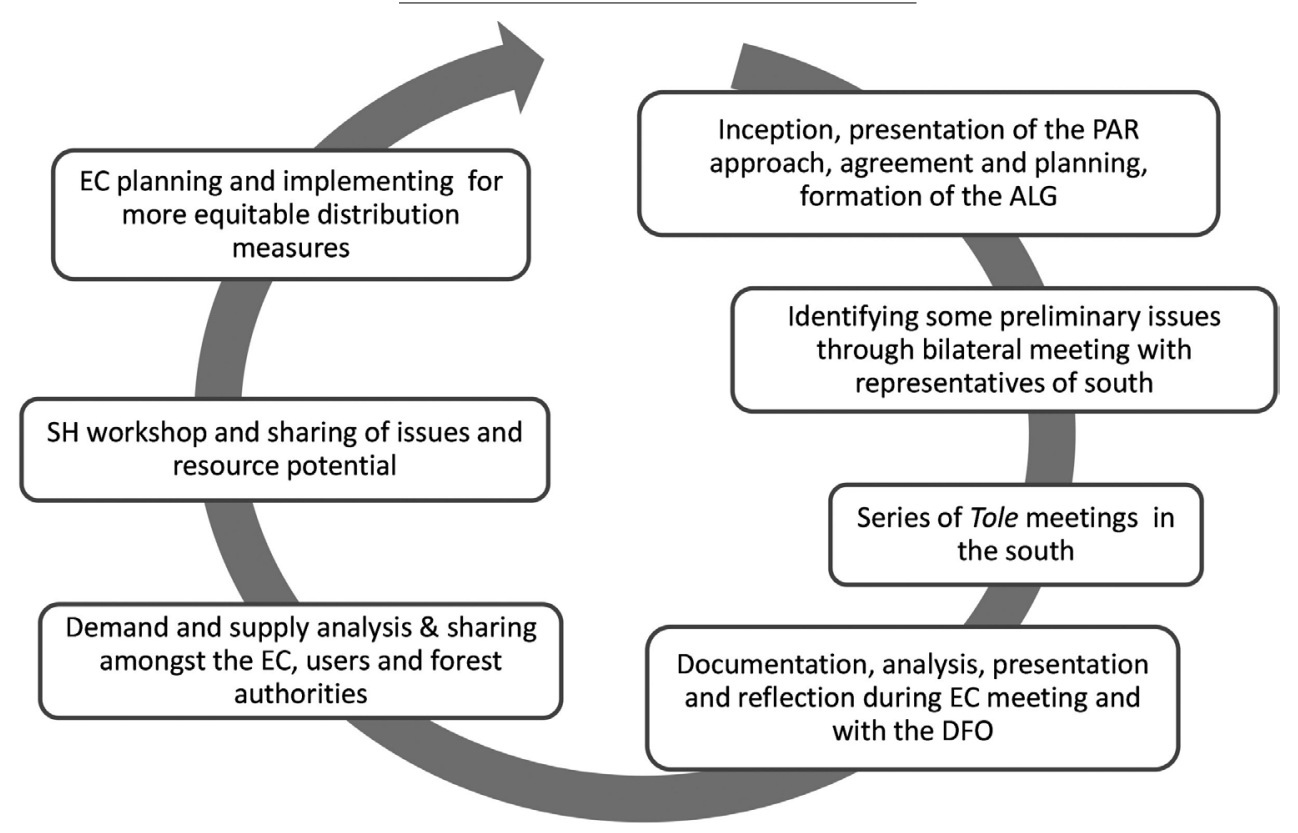

Figure 2: Participatory Action Cycle Deployed at Chisapani CFUG

\section{CFUG INITIATIVES TO FOSTER NORTH-SOUTH DIALOGUE}

The ALG undertook consultation meetings with both northern and southern communities on their perception of their rights and roles in management, access to and relative benefits that people are deriving from forest. The meetings were held in villages covering all wards. During the meeting, people from northern communities claimed that they are nearby and are natural custodians of the forests. They have invested their time and labour in protecting the forest, have put off forest fire that occurs every spring, have opted for alternative sources of energy instead of fuelwood to reduce pressure on 
forests. Similarly they have to keep their cattle in shed as they cannot graze, and only used timber for constructing houses. They also accused southern communities for unsustainable harvesting, that they do not value forest sustainability, do not contribute to its protection but instead illegally take cartloads of timber, fuelwood and other forest products by often coming in large numbers.

Contrary to these statements, we found very different claims when we organised meetings with the southern communities. They claimed that they were the traditional users of that forest while the northern communities who migrated less than 30-40 years ago now controlled the forest in the form of community forest. They also said that since losing their access to forest resources, they are compelled to use cow dung for cooking. Furthermore, they claim that it is difficult to find timber even if they are ready to pay for it. These southern communities also expressed that the forest is far so they only collect forest products once or twice in a year while the northern communities enter the forest at their will. It was further claimed that the northern communities have benefitted from the forest with very little inputs. We observed that most of these perceptions were based on inadequate understanding of the actual situation and were largely based on perceived inequity regarding access to forest resources. These meetings were followed by reflections during the next rounds of executive committee meetings involving all stakeholders. These meetings provided opportunities for the southern communities to share their views, concerns, and grievances which, they had been experiencing over the years. The EC leaders also had the opportunity to better appreciate their real situation and hence clarify their limitations.

\section{COLLECTIVE INQUIRY OF BIOPHYSICAL AND SOCIAL ASPECTS}

The analysis of biophysical and social aspects was conducted by the ALG. The activities thus conducted involved forest inventory, growing stock, mean annual increment and annual allowable harvest based on the approved management plan. Broader ecosystem services including sources of water, soil conservation and greenery through which both northern and southern communities benefited were also assessed. These assessments provided potentials of the forest in supplying key products. In consultation with the leaders of the community forest and those of southern communities, fuelwood need of both communities based on everyday use in cooking, religious and social functions, and funeral were then analysed (Table 1). The annual fuelwood need (i.e. 1,999 tonnes) was way below the supply of 508.4 tonnes. Similarly, timber need based on estimated house construction each year was calculated at 25,125 cft, while the supply as per the management plan was around 1,300 $\mathrm{cft}$. These figures show huge gap between the need and actual supply of timber and fuelwood in the community forest. 
Table 1: Estimated Demand and Supply of Fuelwood and Timber in Chisapani CFUG

\begin{tabular}{|c|c|c|c|c|}
\hline \multicolumn{2}{|l|}{ Feulwood [quintal (qt)/year] } & \multicolumn{3}{|c|}{ Timber (cft) } \\
\hline Purpose & Demand & Supply & Demand & Supply \\
\hline $\begin{array}{l}\text { Funeral rituals: } 187 \text { dead bodies } \\
\text { (assuming } 1 \% \text { die per year) x } 8 \\
\text { qt of fuel wood for each }\end{array}$ & 1488 & & & \\
\hline $\begin{array}{l}\text { Wedding: } 928 \text { (assuming } 5 \% \text { of } \\
\text { HHs per year) x } 4 \text { qt for each }\end{array}$ & 3712 & & & \\
\hline $\begin{array}{l}\text { For religious occasions: }(1 \% \\
\text { of } \mathrm{HHs} \text { per year which is } 335 \\
\mathrm{HHs}) \mathrm{x} 4 \mathrm{qt} \text { per yr }\end{array}$ & 1340 & $\begin{array}{l}4800 \mathrm{qt} / \mathrm{yr} \\
\text { (base on } \\
\text { OP) }\end{array}$ & $\begin{array}{l}\text { House } \\
\text { construction } \\
\text { (assuming 15\% } \\
=502 \mathrm{HHs}\end{array}$ & $\begin{array}{l}1300 \\
\text { cft(based } \\
\text { on OP) }\end{array}$ \\
\hline For schools: public purposes 50 & 50 & & require timber & \\
\hline $\begin{array}{l}\text { Regular cooking: } 3350 \mathrm{HHs} \times 4 \\
\text { qt per year }\end{array}$ & 13400 & & $\begin{array}{l}3350 * 15 \% * 50 \\
=25125 \mathrm{cft}\end{array}$ & \\
\hline Total & $19990 \mathrm{qt} / \mathrm{yr}$ & & & \\
\hline
\end{tabular}

* Based on CFUG yearly demand and supply system of last five years.

\section{REFLECTIONS ON THE DEMAND-SUPPLY GAP: ACTUAL USES AND DIFFERING PERCEPTIONS}

Following the completion of assessment of the users' need and that of community forest's potential to supply the key forest products, it was realised that there were two important aspects fuelling the conflict. First, there were serious gaps in forest product supply and demand so that people had to resort to illegal and unsustainable harvesting measures, or had to cope with costly and inconvenient substitute. For example, they had to use cow dung cake for cooking instead of using it in the farmland for manure. Similarly, they were using weak but expensive substitution such as aluminium and plywood from the market. Second, and equally important, is the everyday experience of humiliation and unpleasant behaviour such as encounters during collection and transport of timber and fuelwood. After analysing the demand supply gaps and the conflicting perceptions of northern communities and southern communities, the team developed a concrete workable and acceptable strategy to mitigate the conflict. The strategy included change in community forest institutional features, governance process and rules with regard to accessing forest products.

\section{CHANGES IN INSTITUTIONAL FEATURES AND DISTRIBUTIONAL ARRANGEMENTS}

Various strategies were adopted by the ALG in order to address the conflicting issues between the northern and southern communities. First, adequate representation and meaningful participation of southern communities in CFUG governance was ensured. 
Second, rules regarding access to forest products were revised. Third, plantation and protection of forest in the southern communities were planned. These strategies have resulted in some significant outcomes. They have now changed the CFUG's constitution that now recognises southern communities as legitimate members with full rights to participate in all institutional processes including the general assembly, executive committee and sub-committees. The approach was also in line with the government policy in encouraging inclusion of the southern communities. It has helped to develop a sense of ownership among the southern communities too. There is now reservation for southern communities in the executive committee (increased by 30\%) and other sub-committees that ensure their representation.

In addition to other initiatives, the CFUG has also revised its forest management rules. These include change in opening time, the process for applying and collecting timber and fuelwood, and better communication of forest opening times among others. They also established a new depot for timber and fuelwood for the convenience of the southern communities. Moreover, they have developed a monitoring mechanism of these actions, formed five-member subcommittee which include all southern communities for the management of the depot. In addition, they have also improved information flow about key institutional processes, and forest product harvest and distribution. The southern communities have benefitted from these measures and have received significantly more timber and fuelwood than in the past and in a much easier way (for wedding, funerals, religious events and during winter: about four quintal/HH for each event). This has increased their participation in forest management and livelihood generation activities (in forest patrolling, plantation, regular thinning, weeding, minimised grazing, fish farming, different livelihood and entrepreneur groups). Moreover there has also been a decline in unsustainable and illegal collection of timber and fuelwood.

A CFUG member residing in the southern side of Chisapani opined;

Recognising and strengthening our situation has changed our ways of collecting firewood. We used to collect it haphazardly and whenever and bowever we wanted to, but now, we get it from the depot nearby. This has reduced our time and effort and saved money that we previously had to invest for transportation of fuelwood from forest along the highway which was approximately $18 \mathrm{~km}$ away.

Similarly, they have increased their investment (a nursery was established to produce more than 100,000 seedlings every year) for plantation and protection activities in public land that could contribute to addressing part of the forest product demand in the southern communities. They have incorporated these strategies into the CFUG Operational Plan (OP) and have acquired approval from the DFO. Similarly, the DFO has expanded the existing community forest areas by adding remaining adjacent forest. This has helped in including $\mathrm{HHs}$ from southern communities as members and fulfill their needs. Additionally, the CFUG is now under government's scientific forest management scheme and has harvested substantially more timber and fuelwood compared to the previous years. 
An Assistant Forest Officer in Bardaghat shared;

...there are potential areas around existing community forests in Nawalparasi which are de facto open access and can be brought under the existing CF scheme. Out of 35 registered CFUG in the southern communities in Nawalparasi, all have potential areas that can be expanded as community forests". He added, "Apart from reducing the demand-supply gap, this would ensure that all the forests in the area are sustainably managed. The Chisapani community forest has set an example on this and I think it can be scaled out and adopted in other community forests across the Terai region of Nepal.

\section{DISCUSSION}

Conflicts over forests in the Terai region of Nepal have received central stage in academic literature, policy debate and everyday struggle. The paper took a specific form of conflict - conflict between the hill migrants (northern community people) and the traditional forest users in the southern communities. While the conflicts emerged and sustained due to the loss of traditional access to forest of southern communities, there are other additional factors that contribute to the north-south conflict. These are migrants vs. traditional identities, differential access to state resources, and the recently emerged identity-based politics among others. While the identity politics appear in the face value, the forest conflicts are part of substantive conflict on the ground.

Review of previous initiatives by the state in increasing access of the southern communities to forest products shows that there has been limited achievement in actually addressing the issue. Still, a large section of the southern population is devoid of forest products - timber and fuelwood. Early policies on migration, resettlement and construction of the East-West highway often contributed to distancing the traditional people from forests. Expansion of CF in Terai since the mid-1990s also did not help much as it was conceptualised and constituted in such a way that the southern communities gradually got marginalised. As a desperate move to stop CF and promote alternative modality, the government introduced CFM. However, CFM's potential to serve the southern communities was constrained by three factors. First, its institutional arrangement is too large, complex, and controlled by a bureaucratic process which is hardly accessible to any ordinary citizen. Second, the expansion of CFM was quite slow. Third, as most of the forests have been allocated to other management modalities already, often serving conservation objectives, there is limited potential for further expansion. Similarly, limitations of the PLF have also been presented above. In summary, the paper urges the need for exploring other available options and CF seems to have a good complementary role in addressing the issue.

We are also aware that the government has declared Chure region as an environmental protection area and aims at protecting the landscape by adopting minimum use approach. However, the Chure landscape has also diverse types of forests and some section of this can be managed under CF with different management intervention and some of 
which can be put into minimum use along with good conservation measures. In fact, Chisapani represents hundreds of community forests in the region with an expanded and inclusive approach. This can be an opportunity remaining government managed forests as community forests, and can accommodate more people from the southern communities.

The case of Chisapani CFUG shows how extended and inclusive CF can help to address the question related to access of forest products of the southern communities and therefore, reduce conflict. Originally, CF was meant for communities residing nearby any forest patch(es). However, this approach has largely left out the traditional users of forests that usually fall along the Chure and those living in North of the highway. This CFUG has now included members from up to $18 \mathrm{~km}$ away to make this 'extended' or 'inclusive'. By accommodating the traditional communities from the south as members of the CFUG and also in ECs, Chisapani has now formally become a unique case of a CFUG differing from most of other CFs. They have made three important changes in the normal CF. Firstly, they included the southern communities which is normally not the norm. Secondly, they have revised the arrangements for distributing forest products - mainly timber and fuelwood. Thirdly, they have allocated some of their funds aimed at forest development in the southern communities. These initiatives have helped to reduce both material injustice and perceived exclusion of the people in the southern communities. Consequently, we observed substantially improved collaboration between the northern communities and southern communities in forest management.
One of the major observations is that restructuring of the institution (i.e. CFUG) and changing of the benefit sharing arrangements was possible due to decentralised forest management. The CF policies and laws have entrusted the CFUGs as a self-organized entity to identify its own members and develop their own rules of forest management and benefit-sharing. Due to collective action at the local level, the leadership can take decisions on behalf of the group and negotiate with southern communities. The CFUG leadership took the initiative due to a strong sense of ownership over the institution and the forest. The CFUG was a fully authorized and legitimate entity to initiate dialogue, make amendments in its own constitution and change the rules of forest management and access by revising the OP. This assured the southern communities' leaders to engage with the CFUG and support its revised initiatives. This was how the conflict was substantially reduced.

In this case, we can see that the DFO has offered its implicit support for an extended and inclusive CF. Their initial encouragement followed by handing over of additional forest area helped a lot to address the huge gap in demand and supply. It can be argued that the legal recognition and institutional support to the CFUGs to take such initiative by the forest authority would help to scale out such experiences elsewhere.

The case of Chisapani shows that adaptive learning approach to CF management can forge dialogue within CFUG and also with southern communities and forest authorities. Two aspects - a strong commitment to include southern communities and adoption of the adaptive approach that helped them to think 
outside of the box, on questions of how can conflict between northern communities and southern communities be resolved, has helped to achieve these outcomes. The commitment to transform Chisapani as an inclusive community forest drove them to change their constitution to allow members from the southern communities, increased representation in the EC from the southern communities and increased participation in general assembly and other important decision making forums. Similarly, the adaptive learning approach was useful in integrating biophysical and institutional knowledge that substantiated dialogue and helped in reaching negotiated arrangements. The assessment of the resource potential, that of the demand situation and costs that people are putting in CF management all helped the group to change its current distributional arrangement. Presentation of a clear picture of the demand-supply situation helped the leaders to appreciate and understand each others positions and prepared them to rethink about their own positions which made negotiations possible. Increasing the user base in the southern communities and gradual shift towards increased rule compliance has also reduced monitoring and protection cost of the CFUG, especially the northern communities.

\section{CONCLUSION AND POLICY IMPLICATIONS}

The paper has identified multiple drivers of forest conflicts in Terai emanating from biophysical features of landscape to government policies on migration, infrastructure development and forest management. It is learnt that while major chunk of remaining forests is in and around Chure, densely populated settlements of traditional users live in the far south. In between the two are the hill migrants. With expansion of the $\mathrm{CF}$ programme in Terai, these new comers have organised themselves and have proactively taken control of the forest and its management. Unfortunately, the expansion of CF has resulted in dwindled southern communities' access to their traditional resource base.

The paper also examined the diverse strategies to increase southern communities' access to forests. Introduction of CFM and investment in PLF are some of the major strategies. However, these approaches faced multiple changes and have their respective limitations. Therefore, the need to explore an alternative, viable and acceptable approach to increase southern communities' access is established in this paper.

The expansion of community forest is often restricted in many parts of Terai as it has not facilitated the aforesaid objective. In fact, this has become one of the most appealing critiques of $\mathrm{CF}$ in Terai. However, the case discussed in this paper showed the prospects of increasing southern communities' access to forest and thereby addressing the conflict. While some debates and inadequate attempts have been made in the past, this has become the first successful case. The case showed that extended CF can be a preferred strategy to help increase access and use of forest products by those who are otherwise devoid of it.

Evidence being presented in the paper showed that centralised and bureaucratic approach to handle forest conflict have little success. Wherever, such approach worked, there are tradeoffs to the northern 
communities. As the case showed, the CF leadership was able to capitalise on its legitimate authority to mobilise northern communities, negotiate with the southern community leaders, and also take a number of initiatives in rearranging institutional architecture and benefit distribution arrangements. This was possible due to the CF programme and the recognition of CFUG to handle such issues. The DFO's encouragement including handover of additional forest areas further facilitated the process. The CFUG leaders had the ambition to become a model in the district by showcasing this approach. As the CFUG is at the core of this initiative, it has become much more grounded and shows the prospect of sustainability, and can inspire many others. At the same time, the intensive interactions with other neighboring groups, the DFO, and other stakeholders have also provided them critical feedback and in turn are inspired by their approach to include southern communities. This also shows the prospects of scaling out of the experiences to other similar groups in the region. As the paper shows, forest tenure reform can be attributed to such local initiative in redesigning the governance and distributional arrangement.

Not all CFUGs have taken such initiatives, however. Therefore, one can attribute this case partly to external interventions. It is clear that approaches such as PAR and adaptive learning help to understand biophysical and socio-institutional dimensions of conflict and ultimately contribute to the design of a fair benefit distribution arrangement. In this case, external influence could not be overestimated. As the paper showed, initial encouragement by the DFO which was later complemented by the action research intervention had critical influence. While, national policies and legal structure do not post specific restrictions in adopting this practice, local institutional practice and recently formed local governments may see it in different way often discouraging inclusion of users from other municipalities in the southern communities. However, in this case, these methodological approaches have been further tested, refined and can be implemented by other potential groups in the Terai. Apart from the political will of the CF leadership, PAR and ALG can prove to be a useful tool to systematically approach the conflict, understand it and craft a mutually agreeable institutional arrangement(s).

\section{ACKNOWLEDGEMENTS}

This paper is based on research conducted under the Community-based Adaptive Learning in management of Conflicts and Natural Resources in Bangladesh and Nepal (CALCNR) project. The project was supported by the Netherlands Organisation for Scientific Research (NWO) grant no. W 07.68.2012.424 with funding from the United Kingdom Department for International Development (DFID). We are grateful to our colleagues and the leaders and members of all of the participating CFUGs, FECOFUN and anonymous reviewers.

\section{REFERENCES}

Baral, J.C., Shrestha, M.K. and Sharma, K.P. 2006. Quest of Participatory Forestry in Terai (Morang Experience). Banko Jankari, 16(2): 50-57.

CBS. 2011. National Planning and Housing Census. Central Bureau of Statistics, National Planning Commission Secretariat, Government of Nepal. 
Conway, D., Bhattarai, K. and Shrestha, N.R. 2000. Population-Environment Relations at the Forested Frontier of Nepal: Tharu and Pahari Survival Strategies in Bardiya. Alied Geography, 20(3): 221-242.

DFRS. 2014. Terai Forests of Nepal (2010 - 2012). Forest Resource Assessment Nepal Project/ Department of Forest Research and Survey, Ministry of Forest and Soil Conservation, Government of Nepal.

Ghimire, K. 1992. Forest or Farm: the Politics of Poverty and Land Hunger in Nepal. Delhi: Manohar Publishers.

LFP. 2003. Hill Livelihoods Baseline Study: A Report of the Livelihoods and Forestry Programme. Livelihood and Forestry Programme, Kathmandu, Nepal.

MSFP. 2015. Public Land Management in Southern Terai: Opportunity for Better Livelihood. Multi-Stakeholder Forestry Programme, Kathmandu, Nepal.
Ojha, H.R. 2007. Engaging Bourdieu and Habermas to Reframe Forest Governance in Nepalese Terai. PhD Dissertation, School of Development Studies, University of East Anglia, Norwich.

Satyal, P. and Humphreys, D. 2013. Using a Multilevel Approach to Analyse the Case of Forest Conflicts in the Terai, Nepal. Forest Policy and Economics, 33: 47-55.

Shrestha, N. R. and Conway, D. 1996. Ecopolitical Battles at the Terai Frontier of Nepal: An Emerging Human and Environmental Crisis. International Journal of Population Geography, 2(4), 313-331.

Sinha, D.R. 2011. Betrayal or Business as Usual? Access to Forest Resources in the Nepal Terai. Environment and History, 17:433-460 